\title{
ARTICLES
}

Submitted 12.13.2016. Approved 01.04.2018

Evaluated through a double-blind review process. Scientific Editor: Wilson Costa de Amorim

Original version

DOI: http://dx.doi.org/10.1590/So034-759020180405

\section{THE ROLE OF PERCEIVED ORGANIZATIONAL SUPPORT IN JOB INSECURITY AND PERFORMANCE}

\author{
Papel da percepção do suporte organizacional na insegurança e desempenho \\ no trabalho

\section{El rol de la percepción de apoyo organizacional en la inseguridad laboral y el desempeño}

\begin{abstract}
In this study, we develop a conceptual model of the relationship between job insecurity and job performance, which is mediated by affective organizational commitment and moderated via perceived organizational support in a Chilean company that has undergone downsizing. In this cross-sectional study, we focused on 400 Chilean employees from the retail sector. Our findings indicate that job insecurity negatively influences job performance, which is a relationship that is partially mediated by effective organizational commitment. Moreover, a high level of perceived organizational support helped intensify the effects of the relationship between job insecurity and affective organizational commitment. To minimize the negative effects of job insecurity on the active employees of a downsizing strategy, an effective intervention is required by developing a more realistic communication in terms of a worker's expectations toward the organization.
\end{abstract}

KEYWORDS I Downsizing, job insecurity, job performance, affective organizational commitment, perceived organizational support

SERGIO ANDRÉS LÓPEZ BOHLE ${ }^{1}$ sergio.lopez@usach.cl ORCID: 0000-0002-6202-4089

\section{MARIA JOSÉ CHAMBEL}

mjchambel@psicologia.ulisboa.pt

ORCID: 0000-0001-6588-7034

\section{FELIPE MUÑOZ MEDINA ${ }^{3}$}

felipeantonio.munoz@usach.cl

ORCID: 0000-0002-0425-2067

\section{BRUNO SILVA DA CUNHA}

bruno.silva@usach.cl

ORCID: 0000-0003-3889-9384

${ }^{1}$ Universidad de Santiago de Chile, Facultad de Administración y Economía, Santiago, Chile

${ }^{2}$ Universidade de Lisboa, Faculdade de Psicologia, Lisboa, Portugal

3Universidad de Santiago de Chile, Facultad Tecnológica, Santiago, Chile

\section{RESUMO}

Este artigo apresenta o desenvolvimento de um modelo conceitual da relação entre a insegurança laboral e o desempenho laboral, mediada pelo comprometimento organizacional afetivo e moderada pelo apoio organizacional percebido em uma empresa chilena, que sofreu um processo de downsizing. Este estudo baseou-se em um desenho de corte transversal em 400 funcionários chilenos do setor de varejo. Nossos resultados apontam que a insegurança laboral influencia negativamente o desempenho laboral, e tal relação é parcialmente mediada pelo comprometimento organizacional afetivo. Verificou-se também que um elevado nivel de apoio organizacional percebido intensifica a relação negativa entre insegurança laboral e comprometimento organizacional afetivo. A fim de minimizar os efeitos negativos da insegurança laboral em relação aos sobreviventes de uma estratégia de downsizing, uma intervenção eficaz é sugerida por meio do desenvolvimento de uma comunicação mais realista em termos de expectativas do trabalhador em relação à organização.

PALAVRAS-CHAVE / Redução de pessoal, insegurança laboral, desempenho laboral, comprometimento organizacional afetivo, suporte organizacional percebido.

\section{RESUMEN}

Este trabajo presenta el desarrollo de un modelo conceptual de la relación entre la inseguridad laboral y el desempeño laboral mediado por el compromiso organizacional afectivo y moderado por el apoyo organizacional percibido en una empresa chilena que ha sufrido un proceso de reducción de personal. Este estudio se basa en un diseño cross-sectional en una muestra de 400 trabajadores chilenos del sector minorista. Nuestros resultados señalan que la inseguridad laboral influye negativamente en el desempeño laboral; efecto que a su vez es mediado parcialmente por el compromiso organizacional afectivo. Además, se encontró que es probable que un alto nivel de apoyo organizacional percibido intensifique los efectos de la relación entre la inseguridad laboral y el compromiso organizacional afectivo. Con el fin de minimizar los efectos negativos de la inseguridad laboral en una estrategia de reducción de personal, se sugiere una intervención eficaz en los trabajadores sobrevivientes mediante el desarrollo de una comunicación más realista en términos de expectativas del trabajador hacia la organización.

PALABRAS CLAVE / Reducción de personal, inseguridad laboral, desempeño laboral, compromiso organizacional afectivo, apoyo organizacional percibido. 


\section{INTRODUCTION}

To survive in a global market characterized by high competition, over the past few decades, organizational restructuring via downsizing has become a popular solution (Guthrie \& Datta, 2008; Shoss, 2017). Downsizing, as a management scheme, aims to eliminate positions or jobs to improve organizational efficiency, productivity, and/or competitiveness (Marques, Galende, Cruz \& Portugal, 2014). This concept has also been viewed as a relevant issue for organizational and employment relations (Arshad \& Sparrow, 2010; Meyer \& Allen, 1991). For instance, Datta, Guthrie, and Pandey (2010) have highlighted many individual and organizational outcomes of such downsizing strategies; e.g., an important factor in the downsizing process is job insecurity, which has been criticized for its negative effect on both organizational and individual performance (Brockner, Grover, Reed, \& Dewitt, 1992; Brockner et al., 2004; De Witte, 1999). Because of its importance, job insecurity is defined as the perceived fear of being dismissed from the workforce, as well as a stressor of a threatening work situation.

In this study, we consider that job insecurity may be generated via a downsizing context, which leads to a sense of uncertainty for employees who fear losing their job. Hence, there is a strong negative impact on their attitudes, emotions, and behaviors. In line with previous research (Antón, 2009; Appelbaum, Delage, Labib \& Gault, 1997; Datta et al., 2010; Ruvio \& Rosenblatt, 1998; Schumacher, Schreurs, Van Emmerik, \& De Witte, 2015), we set out to understand the negative relationship between job insecurity and employees' job performance.

Moreover, in line with the definition of survivors, who are a group of workers that have not been laid off and remain in the organization (Brockner et al., 2004, p. 76), we consider that such employees develop a survivor syndrome (Appelbaum et al., 1997; Blackmore \& Kuntz, 2011; Brockner et al., 1992; Sahdev, 2003). This syndrome is characterized by symptoms such as "anger, depression, fear, distrust, and guilt” (Devine et al., 2003 as cited in Marques et al., 2014, p. 933). Consequently, these negative emotions have a significant impact on how workers respond in terms of their attitude and work-related behavior (Brockner et al., 1992; López, Bal, Jansen, Leiva, \& Alonso, 2017). Thus, in this study, we propose an affective mechanism that enables an understanding of job insecurity's negative correlation to job performance. In fact, we consider that affective organizational commitment can act as a mediator between job insecurity and job performance (De Cuyper \& De Witte, 2006; Greenhalgh \& Rosenblatt, 1984; Wang, Lu, \& Siu, 2015). Although job insecurity generates emotional reactions in employees, such as affective organizational commitment (Meyer \& Allen, 1991), in the context of downsizing, job performance is directly affected by job insecurity (Allen, Freeman, Russell, Reizenstein \& Rentz, 2001; Schumacher et al., 2015). Thus, because of such importance and in line with similar studies (Arshad \& Sparrow, 2010; Marques et al., 2014), we propose that affective organizational commitment assumes a partial mediatory role between job insecurity and job performance.

Although the literature distinguishes between the two other forms of commitment, i.e., continuance and normative (Meyer \& Allen, 1991), affective commitment, which presupposes an emotional liaison and identification with organizational values and goals, is characterized by workers wishing to remain in the organization. This attitude subsequently promotes task performance and organizational citizenship behaviors (Meyer, Stanley, Herscovitch, \& Topolnytsky, 2002). Furthermore, as shown by Rodrigues (2011), continuance commitment overlaps with organizational entrenchment and both are delimited by affective commitment, which represents an employee's emotional liaison with the organization.

Thus, we expect that perceived organizational support acts as a relationship mediator between job insecurity and affective organizational commitment, as well as this relationship to be stronger when employees perceive a high organizational support compared to when they perceive low organizational support. Perceived organizational support may be defined as the worker's belief of the organization's consideration of his/ her contributions, and the extent to which the organization is concerned about the worker's well-being (Eisenberger, Huntington, Hutchison, \& Sowa, 1986). Based on employees' expectations that are not met by organizations, we propose a betrayal perspective (Elangovan \& Shapiro, 1998) to understand the influence of perceived organizational support on the relationship between job insecurity and affective organizational commitment. Bal, Chiaburu, and Jansen (2010) considered the betrayal perspective as the inconsistency of expectations in social relationships, i.e., the worker expects the organization to play a supporting role but the organization does not meet his/her expectations. Thus, we expect perceived organizational support to be a contextual factor that moderates the relationship between job insecurity and affective organizational commitment.

Finally, we present both theoretical and practical implications. Through theoretical implications, our model promotes understanding of negative effects of job insecurity on job performance. Moreover, we place greater emphasis on how this effect will partially mediate affective organizational commitment. Our study also contributes to the existing knowledge on the moderating role of perceived organizational support in the 
relationship between job insecurity and affective organizational commitment. Thus, we believe a better understanding of the psychological dimensions that motivate organizational performance and, consequently, their contributions to the creation of a more robust theoretical background will be possible.

This study aims to provide practical information aiding the development of strategies that minimize the negative effects of job insecurity in both workers and organizations. Thus, to successfully plan and implement procedures for the post-dismissal working environment, possible suggestions are provided that may be used in the future. Finally, this study also aims to provide new evidence that will contribute to a better understanding of the employees' value within an organization such that the performance-related aims can be effectively achieved. Therefore, organizations should focus their efforts on establishing a solid employment relationship with their workers. To illustrate this relationship, a conceptual model has been developed, which is shown in Figure 1.

\section{Figure 1. Conceptual model of the current study}

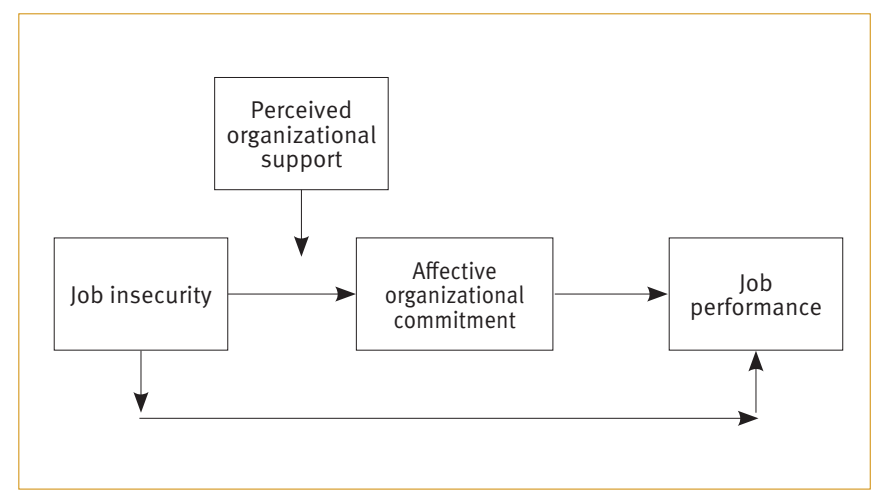

\section{THEORETICAL FRAMEWORK}

\section{Job insecurity and job performance}

The environmental landscape, characterized by ever increasing and unstable changes, has prompted companies to adapt by developing management strategies such as downsizing. This process, viewed as a planned reduction of the workforce, is a means to increase organizational competitiveness and productivity (Datta et al., 2010). Similarly, changes in the industrial environment, which has shifted from a dominant manufacturing-based economy to a service-based economy, are one of the key factors responsible for generating job insecurity in employees' perception (Greenhalgh \& Rosenblatt, 1984; Sora, Caballer, \& Peiró, 2010). Hence, because of the adoption of a strategy that achieves higher levels of performance with a lower workforce, there has been a significant increase in the fear of being laid off (Lim, 1996; Roskies \& Louis-Guerin, 1990). Given the importance of this context, job insecurity is defined as "the perceived powerlessness to maintain desired continuity in a threatened job situation" (Greenhalgh \& Rosenblatt, 1984, p. 438) and a subjective and perceptual phenomenon (Brockner et al., 1992). This indicates that employees who experience job insecurity are uncertain if they will be able to continue working or whether they will lose their jobs in the near future (Ashford, Lee, \& Bobko, 1989; Sverke \& Hellgren, 2002). Thus, because of unexpected changes, a sudden shift from a feeling of security at the workplace to one of insecurity may negatively affect both the well-being and performance of workers (Blackmore \& Kuntz, 2011).

Similar to previous studies (Blau, 1964; Gouldner, 1960), our study is based on the social exchange theory, which provides an adequate perspective to understand whether job insecurity is negatively related to job performance. The social exchange theory (Blau, 1964; Gouldner, 1960) states that reciprocity stimulates a feeling of obligation toward others, primarily because the latter have exhibited past behavior that has proven to be beneficial. Similarly, for individual performance, if an organization treats its employees fairly, they are expected to respond positively (Coyle-Shapiro, 2002; Turnley, Bolino, Lester, \& Bloodgood, 2003). However, employees may decrease their level of individual performance when they feel betrayed by the organization (De Cuyper \& De Witte, 2006; Robinson \& Morrison, 1995). Similarly, when employees feel that the organizations have not fulfilled their obligations or kept their promises, their individual performance has been proven to be negatively affected (Robinson \& Morrison, 1995; Turnley et al., 2003).

Thus, when workers feel that their position in the organization is threatened (i.e., job insecurity), they will perceive that the organization is not fulfilling its obligations and reciprocate with the similar levels of obligations toward the organization, resulting in lower performance (Ashford et al., 1989). For example, De Cuyper and De Witte (2006) and Armstrong-Stassen (1993) empirically confirmed that the perception of job insecurity was associated with a lower job performance (self-rated). Similarly, the meta-analytic research and review, developed by Cheng and Chan (2008) and Shoss (2017), respectively, supported this negative relationship between job insecurity and job performance. Based on this theory, an increased perception of job insecurity is expected to diminish the job performance of employees. Thus, hypothesis 1 has been formulated as follows:

$\mathrm{H}_{1}$ : Job insecurity negatively influences job performance. 


\section{Affective organizational commitment as a mediator}

Affective organizational commitment is one of the most important variables to explain how employees become attached to their organization because of job insecurity. Affective organizational commitment has been conceptualized as "an employee's emotional attachment, identification, and involvement with the organization" (Moshoeu \& Geldenhuys, 2015, p. 26). Similarly, Luchak and Gellatly (2007) consider affective organizational commitment to be a subjective experience in which the worker perceives acknowledgment, on the part of the organization, of his/ her own contributions. Employees who are emotionally committed to an organization may sense a feeling of belonging, which involves a spontaneous and personal desire to consider their own issues along with the organizational matters and develop their work better (Meyer \& Allen, 1991; Meyer, et al., 2002; Siders, George, \& Dharwadkar, 2001; Tian, Zhang, \& Zhou, 2014).

Furthermore, the social exchange theory (Blau, 1964), "reflecting the socio-emotional aspects of the employment relationship, and thus the perceived quality of the employment relationship" (Bal et al., 2010, p. 257), may be used to understand the relationship between job insecurity and affective organizational commitment. As mentioned previously, this theory suggests that the parties of a relationship develop mutual exchanges and search for reciprocity. Thus, when the organization does not meet employees' expectations, such as providing job security, employees consider the organization to have failed in its reciprocity and reduce their level of affective commitment toward the organization (Arshad \& Sparrow, 2010; Lee \& Jeong, 2017). Thus, job insecurity plays a threatening role in terms of employees' interests and values, which weakens their affective organizational commitment (De Witte \& Näswall, 2003). For example, Allen et al. (2001) observed that, during a downsizing process, a decrease in job security was a predictor of a decrease in organizational affective commitment. Marques et al. (2014) empirically confirmed this negative relationship between job insecurity and affective commitment during a downsizing process.

However, based on the hypothesis that emotional connections are relevant at workplaces, employees who are committed to the organization, whether simply because they like it or identify with it, are expected to maintain positive behaviors in terms of job performance (Casimir, Ngee Keith Ng, Yuan Wang, \& Ooi, 2014; Ugboro, 2003; Wang et al., 2015). Balogun, Adetula, and Olowodunoye (2013) studied the importance of this influence by verifying the association of affective organizational commitment with high performance, high organizational citizenship behaviors, and low absenteeism. Thus, for a downsizing process, it is our view that employees' negative appraisal of their job context (i.e., job insecurity) causes a reduction in their affective commitment, which may generate a negative result in the workplace, particularly in terms of their performance (Buitendach \& De Witte, 2005; Cheng, Huang, Lee, \& Ren, 2012; Lee \& Jeong, 2017). In fact, Marques et al. (2014) showed that, during a downsizing process, job insecurity is negatively related to affective commitment, which was in turn related to innovative behaviors.

Therefore, in this study, we focused on the role of affective organizational commitment as a mediator in the relationship between job insecurity and job performance. Hence, hypothesis 2 was formulated as follows:

$\mathrm{H}$ 2: Affective organizational commitment will mediate the relationship between job insecurity and job performance such that job insecurity will negatively relate to affective organizational commitment, which will positively relate to job performance.

Perceived organizational support as a moderator of the relationship between job insecurity and affective organizational commitment

The concept of perceived organizational support is based on studies published by Eisenberger et al. (1986). Their definition referred to perceived organizational support as the dimension in which people believe that their organization considers their contributions and is concerned about their well-being. Moreover, perceived organizational support may be observed when employees feel valued by the organization (Allen, Shore, \& Griffeth, 2003; Kurtessis, Eisenberger, Ford, Buffardi, Stewart, \& Adis, 2017; Rhoades \& Eisenberger, 2002). This concept is considered important as it is based on the defense of a supportive work environment, which is often referred to as being responsible for improving the employees' work-related attitudes and behaviors in the context of downsizing (Tian et al., 2014). However, considering how employees perceive this support to understand its consequences is important.

In this study, we propose to explain the impacts of perceived organizational support, which moderates the relationship between job insecurity and affective organizational commitment. The betrayal perspective (Elangovan \& Shapiro, 1998) argues that when trust is violated, a high perception of support may aggravate the negative effects on workers' attitudes and work behaviors. In line with this assumption, Suazo and Stone-Romero (2011) observed that perceived organizational support strengthened the relationship between the psychological contract breach and violation, the negative relations between this 
breach or violation, and supervisor-rated employee citizenship behaviors.

According to previous studies, the most significant act of betrayal involves the closest and most important relationships, among which the relationship with the organization may be included. In fact, Eisenberger et al. (1986) argued that employees developed perceived organizational support based on an accumulation of rewards received over time. Thus, an employee's history of rewards, which were obtained from various human resource practices and decisions, would contribute to perceived organizational support (Wayne et al., 1997). A downsizing process indicates that employees are not considered important for either the survival or success of the organization. Furthermore, it suggests disinvestment in employees and shows that their contributions are not recognized (Costa \& Neves, 2017). Indeed, job insecurity caused by the downsizing process indicates an organizational disinvestment and under-commitment toward the employee. Therefore, this practice is inconsistent with the perception of a high support that is generated when higher expectations are associated with the role of employees; moreover, such practices lead to greater pressures and obligations because of increasing job insecurity (Morrison \& Robinson, 1997). Furthermore, according to the betrayal perspective framework (Elangovan \& Shapiro, 1998; Morrison \& Robinson, 1997), failure of the organization to prevent instances of job insecurity may be considered as an act of betrayal too. This is because of errors in safeguarding the principles and expectations that are inherent to a good relationship between the worker and the organization. Employees expect their organizations to provide emotional support and resources, which will lead to attitudes of respect, trust, and mutual obligations (Lynch, Eisenberg, \& Armeli, 1999). However, the employer's failure to prevent instances of increased job insecurity is considered to be an act of betrayal, to which workers will respond by changing their work attitudes and behaviors (Coyle-Shapiro, 2002).

Moreover, according to the hypothesis of expectationviolation, people tend to react strongly to another party's actions when they violate their prior expectations of behavior (Restubog \& Bordia, 2006). Therefore, workers who report high levels of perceived organization support are possibly expected to be helped during a negative work experience such as a higher level of job insecurity. However, in organizations where the workers' expectations have not been fulfilled, the supportive relationship becomes part of the problem and further aggravates the situation of insecurity at the workplace. Thus, according to the expectationviolation framework, employees will decrease their affective commitment.
However, in situations of low organizational support, the theory primarily suggests that the relationship between job insecurity and work attitudes is insignificant (Bal, De Lange, Jansen, \& Van der Velde, 2008; Bal et al., 2010). The reason is that an increase in job insecurity is another sign that workers are not being valued as members of the company (Aselage \& Einsenberger, 2003). Thus, the slope obtained represents workers having low social exchange with their organization, which is essentially flat with low and high levels of job insecurity; consequently, the individual's attitudes remain unaffected.

Based on the abovementioned arguments, our study proposes that with an increase in job insecurity, workers reduce their individual emotional liaison and expect perceived high organizational support. Moreover, when perceived low organizational support is expected, workers do not alter their affective commitment as job insecurity increases. In conclusion, we may hypothesize as follows:

$\mathrm{H}_{3}$ : The relationship between job insecurity and affective organizational commitment will be moderated by perceived organizational support such that this relationship will be stronger when employees perceive high organizational support compared to when they perceive low organizational support.

\section{METHOD}

\section{Design}

An empirical study with a quantitative approach was developed to test our conceptual model (See Figure 1).

\section{Participants}

The participants were selected through a convenience sample that consisted of 400 Chilean employees who had survived a process of organizational restructuring of a private company in the retail sector. The retail sector was selected because it is a highly competitive industry and is significant to the national economy. Over the past few years, the retail sector has overcome numerous rearrangements, and in accordance with official reports, similar restructuring is foreseen in the near future.

In the sample, which was representative of employees from the retail sector, of the 558 employees, 400 employees returned completed questionnaires (response rate $=70 \%$ ).

Table 1 lists the sample's demographic characteristics. We believe that the collected data are in accordance with the demographic trends of the Chilean retail sector. Moreover, according to the observations of Stecher (2012), retail companies 
can be characterized by their workers' heterogeneous profiles, i.e., young and middle-aged males and females who may/may not have prior work experience and a level of schooling that ranges from incomplete school education to completed technical studies. Although there is such heterogeneity, there is a predominance of females (60-80\% in the stores), young adults $(60 \%$ under the age of 35 years), and low-skilled workers without much prior work experience and belonging to popular urban retail stores.

\section{Table 1. Demographic characteristics of the sample}

\begin{tabular}{l|c|c}
\hline \multirow{2}{*}{ Gender \% } & Female & 72.0 \\
\cline { 2 - 3 } & Male & 21.0 \\
\hline \multirow{2}{*}{ Age } & Mean & 34.91 \\
& $($ SD) & $(19.91)$ \\
\hline \multirow{2}{*}{ Qualifications \% ${ }^{2}$} & Up to secondary & 53.0 \\
\cline { 2 - 3 } & Technical studies & 31.0 \\
\cline { 2 - 3 } & Degree & 13.0 \\
\hline \multirow{2}{*}{ Tenure } & Postgraduate studies & 0.5 \\
\hline \multirow{2}{*}{ Work experience } & Mean & 3.79 \\
& (SD) & $(4.99)$ \\
\hline
\end{tabular}

These percentages do not add up to 100 as not everyone responded to this item ${ }^{2} T$ These percentages do not add up to 100 as not everyone responded to this item

\section{Procedures}

The participants were contacted by the human resources department and an informed consent was obtained from them. The questionnaire was answered either at the beginning or end of the working day in one of the meeting rooms within the organization. One of the study's researchers met each group of participants to explain the purpose and requirements of the study. All the participants were assured of complete confidentiality and anonymity of their responses and informed that their participation was completely voluntary. The cover letter accompanying the questionnaire in all the surveys indicated that the study was conducted only for scientific purposes.

All measures used in the study were both translated and back-translated from English and Spanish by two of the authors, working independently, who adopted the proposals of Brislin (1970). To assess the questionnaires' usability, a pilot test of the Chilean version with 30 employees was conducted.

\section{Measures}

To measure job insecurity, we used De Witte's (2000) scale, which had six items (e.g., "I worry about keeping my job") that were answered on the Likert scale ( $1=$ Completely disagree; $5=$ Completely agree).

To measure effective organizational commitment, we used Cook's (1981) scale, which had five items (e.g., "Knowing that my own work had made a favorable contribution to the organization would please me") answered on the Likert scale (1= Completely disagree; 5 = Completely agree).

To measure perceived organizational support, we used the scale developed by Eisenberger et al. (1986), which had seven items (e.g. "My organization would forgive an honest mistake on my part") answered on the Likert scale ( $1=$ Completely disagree; $5=$ Completely agree).

To measure perceived performance, we used Abramis' (1994) scale, which had six items (e.g., "Perform without mistakes?”) answered on the Likert scale (1 = Completely disagree; 5 = Completely agree).

Lastly, a confirmatory factor analysis (CFA) was performed to evaluate the construct validity of the study variables as the scales that were used were Spanish translations of constructs that were validated in English. For this purpose, a five-factor model was tested using all items of the scales: job insecurity, affective organizational commitment, perceived organizational support, and perceived performance. Note that these analyses reported a poor goodness of fit of the model $(x 2=837.121, \mathrm{df}=338, \mathrm{p}=$ $0.0000, \mathrm{RMSEA}=0.086, \mathrm{SRMR}=0.097, \mathrm{CFI}=0.77$, and $\mathrm{TLI}=0.74$ ).

Based on the modification index (Byrne, 2012), we deleted one item each from the affective organizational commitment scale and the perceived organizational support scale and introduced some correlations between residual errors. These modifications resulted in an improvement in the model's fit $(x 2=600.167, \mathrm{df}=$ 240, $p=0.0000 ;$ RMSEA $=0.038 ;$ SRMR $=0.091 ; \mathrm{CFI}=0.80 ; \mathrm{TLI}$ $=0.80$ ). The results showed empirical support for constructing the validity of the four-factor model (job insecurity, affective organizational commitment, perceived organizational support, and perceived performance).

\section{Statistical analysis}

For the data analysis, a three-step strategy was used. First, using the MPLUS 6 program (Muthén \& Muthén, 2010), the factorial validity of the proposed model was evaluated via confirmatory factor analyses and a reliability analysis (Brown, 2006; Byrne, 
2012). These analyses were performed to estimate the robustness of the proposed model's scales, which were supported by the procedure that was described by Bolger, Davis, and Rafaeli (2003).

At the second stage, based on the recommendations of Baron and Kenny (1986), the effects of mediation were examined. Subsequently, to confirm the mediation, the SOBEL (Preacher \& Hayes, 2004) statistical test was performed. For this test, we evaluated whether the reduction of the relationship between the variables that were involved in the mediation was statistically significant. Lastly, at the third stage, the moderation hypothesis was evaluated via a moderate multiple regression analysis (RMM), according to the method suggested by Aiken, West, and Reno (1991). To reduce multicollinearity, the study's variables were centered before calculating interactions (Aiken et al., 1991). Finally, the sign and significance of the interaction terms to identify the address patterns of the variables were assessed. The slopes of the relationship between the independent variable and the dependent variables of each of the moderations that proved to be significant were represented by values of $\pm 1 S D$ from the average. These analyses were performed using the macro MODPROBE, which was developed by Hayes and Matthes (2009) for estimating the interactions of the moderate multiple regression analysis (RMM).

\section{RESULTS}

We evaluated a conceptual model that considered the relationship between job insecurity and job performance, which was mediated by affective organizational commitment and moderated using perceived organizational support.

Table 2 lists the means, standard deviations, intercorrelations, and realities of Cronbach's a in relation to the variables of this study. The correlation matrix shows that the relationship between job insecurity was significant and negative for the variables of affective organizational commitment, perceived organizational support and perceived performance. The mediating variable of affective organizational commitment was positively and significantly related to perceived performance. Moreover, the moderating variable of perceived organizational support revealed a significant relationship with perceived performance, job insecurity, and affective organizational commitment.

Because our sample showed high variability in some characteristics, i.e., age, organization tenure, and position, we decided to introduce these variables as control variables and introduced age (in years), organization tenure (in months), and position (dummy variable: 0 = operative and technical duties; 1 = supervisor and managers).

$\mathrm{H}_{1}$ stated that job insecurity was related negatively to job performance. Moreover, according to the results shown in Table 3, job insecurity was a significant negative predictor of performance $(B=-0.156, p \leq 0.05)$. Thus, $\mathrm{H}_{1}$ was supported.

$\mathrm{H} 2$ stated that affective organizational commitment would have a mediating effect between job insecurity and job performance. In line with this hypothesis, a significant and negative relationship between job insecurity and job performance became weaker when the mediator was integrated into the regression equation (Step 3, B $=-0.134, p \leq 0.05$ ), which indicated partial mediation. Thus, $\mathrm{H}_{2}$ was supported (see Table 3 ).

$\mathrm{H}_{3}$ stated that perceived organizational support could moderate the relationship between job insecurity and affective organizational commitment. The results indicated that the interaction term was significantly related to affective organizational commitment $(B=-0.193, p \leq 0.05)$. Based on the results obtained, the relationship between job insecurity and affective organizational commitment was evidently stronger and more significant at higher levels (+1SD) of perceived organizational support and weaker and insignificant at lower levels (-1SD) of perceived organizational support (see Figure 2). These results supported $\mathrm{H}_{3}$.

Table 2. Means, standard deviations, and correlations of variables

\begin{tabular}{|c|c|c|c|c|c|c|c|c|c|}
\hline 1. Job insecurity & 2.52 & 0.78 & $(0.72)$ & & & & & & \\
\hline 3. Perceived organizational support & 3.37 & 0.76 & -0.157 & * & 0.396 & ** & $(0.83)$ & & \\
\hline
\end{tabular}

Notes: Figures in parentheses indicate the reliability of scales ${ }^{*} p \leq 0.05 ;{ }^{* *} p \leq 0.01$ 
Table 3. Results of mediated regression for job performance*

\begin{tabular}{|c|c|c|c|c|c|c|}
\hline \multicolumn{3}{|c|}{ Variable } & B & $S E$ & $t$ & $P$ \\
\hline \multicolumn{3}{|c|}{ Job performance regressed in job insecurity } & -0.156 & 0.063 & -2.463 & 0.015 \\
\hline \multicolumn{3}{|c|}{ Affective organizational commitment regressed in job insecurity } & -0.164 & 0.086 & -2.128 & 0.035 \\
\hline \multicolumn{3}{|c|}{$\begin{array}{l}\text { Job performance regressed in affective organizational commitment, } \\
\text { controlling for job insecurity }\end{array}$} & 0.325 & 0.066 & 4.380 & 0.000 \\
\hline \multicolumn{3}{|c|}{$\begin{array}{l}\text { Job performance regressed in job insecurity, controlling for affective } \\
\text { organizational commitment }\end{array}$} & -0.134 & 0.058 & -2.286 & 0.024 \\
\hline & Value & SE & & $p$ & & \\
\hline Sobel & -2.30 & 0.023 & & 0.021 & & \\
\hline
\end{tabular}

* We presented the results of the second step after introducing the control variables in the first step: age (in years); organization tenure (in months); position $(0=0$ perative and technical duties; 1 = supervisor and managers).

Figure 2. Interaction effect of perceived organizational support in the relationship between job insecurity and affective organizational commitment

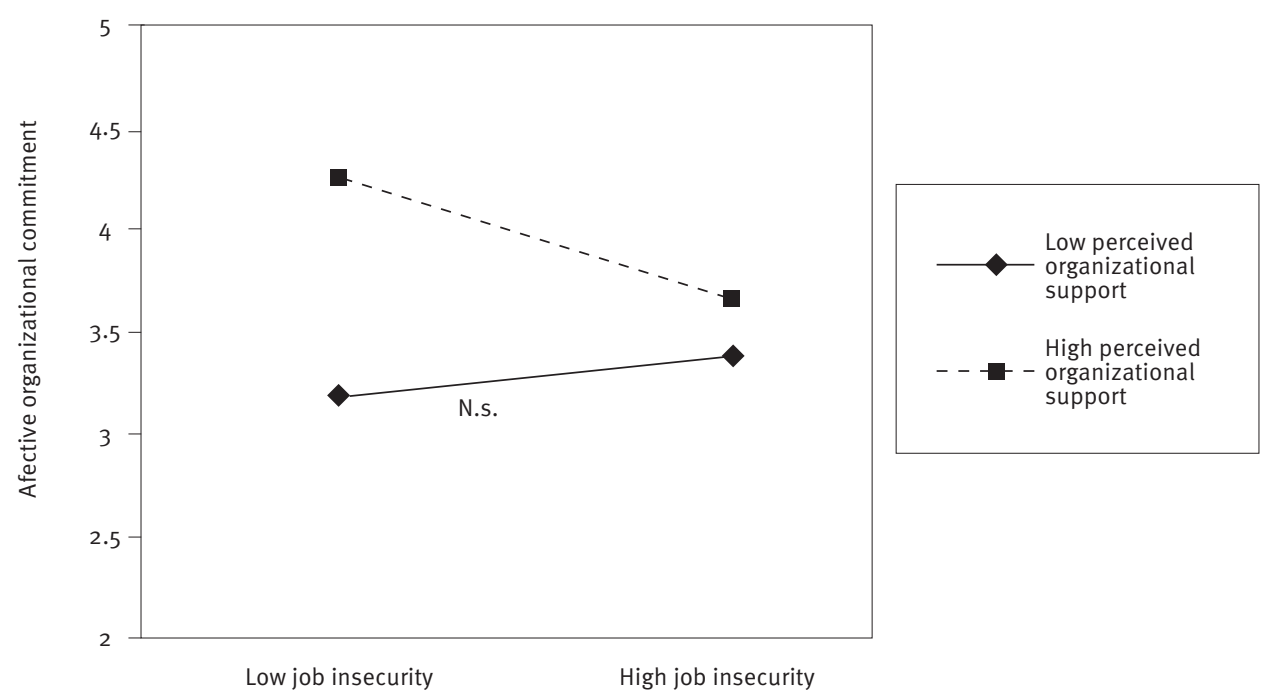

\section{DISCUSSION}

\section{Theoretical implications}

This study is based on theoretical and empirical outcomes and we sought to identify relations of the effects of job insecurity on job performance according to the social exchange theory (Blau, 1964).

Moreover, to understand this relationship, we set out to understand the mediating mechanism (Cheng \& Chan, 2008; De
Witte \& Näswall, 2003; Ruvio \& Rosenblatt, 1998; Schumacher et al., 2015; Sora et al., 2010; Sverke \& Hellgren, 2002; Ugboro, 2003) and the moderating role (Bal et al., 2010; Blackmore \& Kuntz, 2011; Eisenberger et al., 1986; Tian et al., 2014). The observed results of this study confirm the assumptions of the proposed model, i.e., job insecurity is negatively related to job performance, which is better explained by a partial mediation of affective organizational commitment. Moreover, our results 
are consistent with those of the social exchange theory. Therefore, the relationship between job insecurity and affective organizational commitment will be significantly negative. This proves that the core principle of job insecurity playing a threatening role when it comes to employees' interests and values is correct, which ultimately weakens employees' affective organizational commitment. Thus, when employees perceive that organizations have not met their expectations of providing job security, they reduce their level of affective commitment to the organization (Allen et al., 2001; Arshad \& Sparrow, 2010; Marques et al., 2014). Similarly, job insecurity induces a negative response to affective organizational commitment, which then reduces individual performance (Buitendach \& De Witte, 2005; Cheng et al., 2012).

Furthermore, the relationship between job insecurity and affective organizational commitment is stronger at higher levels of perceived organizational support and insignificant at lower levels of perceived organizational support. Considering the data of previously published studies (Bal et al., 2010; Elangovan \& Shapiro, 1998), the abovementioned evidence is in line with the betrayal perspective, i.e., employees perceive the support offered by organizations to be incoherent with their expectations. In fact, when employees perceive their work in a context that considers their contributions and well-being, they expect to receive organizational support to handle and cope with the stresses of uncertain situations (Kurtessis, Eisenberger, Ford, Buffardi, Stewart, \& Adis, 2017; Shoss, 2017; Vandenberghe, Bentein, \& Stinglhamber, 2004). However, when they perceive job insecurity caused by a downsizing process, they sense a disinvestment for the organization, which is inconsistent with the expectations involved in a supportive context. (Morrison \& Robinson, 1997; Costa \& Neves, 2017). Therefore, if the perceived organizational support is not in line with employees' expectations, the betrayal effect may intensify the fear of losing the job and reducing affective organizational commitment (Fried et al., 2003; Siders et al., 2001). Thus, we have contributed to the literature on organizational relationships by highlighting contextual and emotional factors affecting individual performance caused by job insecurity.

\section{CONCLUSION}

This study presents certain limitations that may affect the analysis of results. It was impossible to arrive at any conclusions for causality because of the study's cross-sectional design; hence, we suggest developing longitudinal studies that may help to achieve causal considerations among these variables. Importantly, the sample consisted of workers who had survived an organizational process of downsizing at a Chilean company from the retail sector. Therefore, whether these findings can be extended to another related sample needs to be checked. Moreover, using selfreported variables may raise questions of common-method bias; thus, multiple procedures were used to minimize this effect. To avoid possible modifications and encourage consistent answers, confidentiality was assured to the participants. Furthermore, to generate a favorable environment and obtain realistic answers, the responses were stated to be neither right nor wrong.

Despite these limitations, some important practical implications can be derived from this study. For job insecurity, employees may experience perceptions of uncertainty, which leads to a fear of being laid-off and affects their performance. Indeed, reduced performance may cause weakening of efficiency and organizational effectiveness, which may have a financial impact. Hence, the impact of job insecurity is an important factor that needs to be addressed at workplaces because it involves employees who remain in the organization and survive a downsizing strategy; consequently, our results aim to endorse an efficient downsizing process.

Moreover, for organizations, as an effective intervention strategy, this study suggests that considering the implementation of actions is important. Furthermore, to promote an enabling environment that effectively helps develop affective organizational commitment among the surviving workforce and to prevent negative consequences in the employee-organization relationship, communication and clarification of expectations related to the organization needs to be encouraged.

However, in the relationship between job insecurity and affective organizational commitment, perceived organizational support assumes a significant role. To minimize negative results, the organization should consider the fear of being laid-off within the scope of the insecurity and downsizing process perceived by the employees. Moreover, organizations should consider employees' expectations more demonstratively, i.e., by trying to be more realistic, avoiding false beliefs, and giving emotional support to their workforce.

To summarize, this study sheds light on the negative relationship between job insecurity and job performance, a relationship that is partially mediated by affective organizational commitment. Moreover, a high level of perceived organizational support intensified the negative relationship between job insecurity and affective organizational commitment; however, in the presence of low levels of perceived organizational support, this relationship was observed to be insignificant. 


\section{AUTHOR'S NOTE}

This research was supported by the Proyecto Basal Usach [grant number USA1498_LS022128] of the Universidad de Santiago de Chile.

\section{REFERENCES}

Abramis, D. J. (1994). Work role ambiguity, job satisfaction, and job performance: Meta-analyses and review. Psychological reports, 75(3), 1411-1433. doi:10.2466/pro.1994.75.3f.1411

Aiken, L. S., West, S. G., \& Reno, R. R. (1991). Multiple regression: Testing and interpreting interactions. Thousand Oaks, CA: Sage.

Allen, T. D., Freeman, D. M., Russell, J. E., Reizenstein, R. C., \& Rentz, J. O. (2001). Survivor reactions to organizational downsizing: Does time ease the pain? Journal of Occupational and Organizational Psychology, 74(2), 145-164. doi:10.1348/096317901167299

Allen, D. G., Shore, L. M., \& Griffeth, R. W. (2003). The role of perceived organizational support and supportive human resource practices in the turnover process. Journal of management, 29(1), 99-118. doi:10.1016/S0149-2063(02)00222-2

Armstrong-Stassen, M. (1993). Production workers' reactions to a plant closing: The role of transfer, stress and support. Anxiety, Stress and Coping: An International Journal, 6(3), 201-214. doi:10.1080/10615809308248380

Antón, C. (2009). The impact of role stress on workers' behaviour through job satisfaction and organizational commitment. International Journal of Psychology, 44(3), 187-194. doi:10.1080/00207590701700511

Appelbaum, S. H., Delage, C., Labib, N., \& Gault, G. (1997). The survivor syndrome: Aftermath of downsizing. Career Development International, 2(6), 278-286. doi:10.1108/13620439710178639

Arshad, R., \& Sparrow, P. (2010). Downsizing and survivor reactions in Malaysia: Modelling antecedents and outcomes of psychological contract violation. The International Journal of Human Resource Management, 21(11), 1793-1815. doi:10.1080/09585192.2010.505080

Aselage, J., \& Eisenberger, R. (2003). Perceived organizational support and psychological contracts: A theoretical integration. Journal of Organizational Behavior, 24(5), 491--509. doi:10.1002/job.211

Ashford, S. J., Lee, C., \& Bobko, P. (1989). Content, cause, and consequences of job insecurity: A theory-based measure and substantive test. Academy of Management Journal, 32(4), 803-829. doi:10.2307/256569

Bal, P. M., Chiaburu, D. S., \& Jansen, P. G. (2010). Psychological contract breach and work performance: Is social exchange a buffer or an intensifier? Journal of Managerial Psychology, 25(3), 252-273. doi:10.1108/02683941011023730

Bal, P. M., De Lange, A. H., Jansen, P. G. W., \& Van der Velde, M. E. G. (2008). Psychological contract breach and job attitudes: A meta-analysis of age as a moderator. Journal of Vocational Behavior, 72(1), 143-158. doi:10.1016/j.jvb.2007.10.005
Balogun, A. G., Adetula, G. A., \& Olowodunoye, S. A. (2013). Job conditions, psychological climate, and affective commitment as predictors of intention to quit among two groups of bank employees in Nigeria. Romanian Journal of Applied Psychology, 15(1), 9-19.

Baron, R. M., \& Kenny, D. A. (1986). The moderator-mediator variable distinction in social psychological research: Conceptual, strategic, and statistical considerations. Journal of personality and social psychology, 51(6), 1173-1182. doi:10.1037/0022-3514-51.6.1173

Blackmore, C., \& Kuntz, J. R. C. (2011). Antecedents of job insecurity in restructuring organisations: An empirical investigation. New Zealand Journal of Psychology, 40(3), 7-18.

Blau, P. M. (1964). Exchange and power in social life. New York, NY: Wiley.

Bolger, N., Davis, A., \& Rafaeli, E. (2003). Diary methods: Capturing life as it is lived. Annual Review of Psychology, 54(1), 579-616. doi:10.1146/annurev.psych.54.101601.145030

Brislin, R. W. (1970). Back-translation for cross-culture research. Journal of Cross-Cultural Psychology, 1(3), 185-216. doi:10.1177/135910457000100301

Brockner, J., Grover, S., Reed, T. F., \& Dewitt, R. L. (1992). Layoffs, job insecurity, and survivors' work effort: Evidence of an inverted-U relationship. Academy of Management Journal, 35(2), 413-425. doi: $10.2307 / 256380$

Brockner, J., Spreitzer, G., Mishra, A., Hochwarter, W., Pepper, L., \& Weinberg, J. (2004). Perceived control as an antidote to the negative effects of layoffs on survivors' organizational commitment and job performance. Administrative Science Quarterly, 49(1), 76-100.

Brown, T. (2006). Confirmatory factor analysis for applied research. New York, NY: The Guilford Press.

Buitendach, J. H., \& De Witte, H. (2005). Job insecurity, extrinsic and intrinsic job satisfaction and affective organisational commitment of maintenance workers in a parastatal. South African Journal of Business Management, 36(2), 27-37.

Byrne, B. M. (2012). A primer of LISREL: Basic applications and programming for confirmatory factor analytic models. New York, NY: Springer Science \& Business Media.

Casimir, G., Ngee Keith Ng, Y., Yuan Wang, K., \& Ooi, G. (2014). The relationships amongst leader-member exchange, perceived organizational support, affective commitment, and in-role performance: A social-exchange perspective. Leadership \& Organization Development Journal, 35(5), 366-385. doi:10.1108/LODJ-04-2012-0054

Cheng, G. H. L., \& Chan, D. K. S. (2008). Who suffers more from job insecurity? A meta-analytic review. Applied Psychology, 57(2), 272-303. doi:10.1111/j.1464-0597.2007.00312.x

Cheng, T., Huang, G. H., Lee, C., \& Ren, X. (2012). Longitudinal effects of job insecurity on employee outcomes: The moderating role of emotional intelligence and the leader-member exchange. Asia Pacific Journal of Management, 29(3), 709-728. doi:10.1007/s10490-0109227-3

Costa, S., \& Neves, P. (2017). Job insecurity and work outcomes: The role of psychological contract breach and positive psychological capital. Work \& Stress, 31(4), 1-20.

Cook, J. D. (1981). The experience of work: A compendium and review of 249 measures and their use. London, UK: Academic Press.

Coyle-Shapiro, J. A. (2002). A psychological contract perspective on organizational citizenship behavior. Journal of Organizational Behavior, 23(8), 927-946. doi:10.1002/job.173 
Datta, D. K., Guthrie, J. P., Basuil, D., \& Pandey, A. (2010). Causes and effects of employee downsizing: A review and synthesis. Journal of Management, 36(1), 281-348. doi:10.1177/0149206309346735

De Cuyper, N., \& De Witte, H. (2006). The impact of job insecurity and contract type on attitudes, well-being and behavioural reports: A psychological contract perspective. Journal of Occupational \& Organizational Psychology, 79(3), 395-409. doi:10.1348/096317905X53660

De Witte, H. (1999). Job insecurity and psychological well-being: Review of the literature and exploration of some unresolved issues. European Journal of Work and Organizational Psychology, 8(2), 155-177. doi:10.1080/135943299398302

De Witte, H. (2000). Arbeidsethos en jobonzekerheid: meting en gevolgen voor welzijn, tevredenheid en inzet op het werk. In R. Bouwen, K. De Witte, H. De Witte, \& T. Tailleu, Van groep naar gemeenschap. Liber Amicorum Prof. Dr. Leo Lagrou (pp. 325-350). Leuven, Belgium: Garant.

De Witte, H., \& Näswall, K. (2003). 'Objective’ vs ‘subjective' job insecurity: Consequences of temporary work for job satisfaction and organizational commitment in four European countries. Economic and industrial democracy, 24(2), 149-188. doi:10.1177/0143831Х03024002002

Eisenberger, R., Huntington, R., Hutchison, S., \& Sowa, D. (1986). Perceived organizational support. Journal of Applied Psychology, 71(3), 500-507. doi:10.1037/0021-9010.71.3.500

Elangovan, A. R., \& Shapiro, D. L. (1998). Betrayal of trust in organizations. Academy of Management Review, 23(3), 547-566. doi:10.2307/259294

Fried, Y., Slowik, L. H., Shperling, Z., Franz, C., Ben-David, H. A., Avital, N., \& Yeverechyahu, U. (2003). The moderating effect of job security on the relation between role clarity and job performance: A longitudinal field study. Human Relations, 56(7), 787-805. doi:10.1177/00187267030567002

Gouldner, A. W. (1960). The norm of reciprocity: A preliminary statement. American Sociological Review, 25(2), 161-178. doi:10.2307/2092623

Greenhalgh, L., \& Rosenblatt, Z. (1984). Job insecurity: Toward conceptual clarity. Academy of Management review, 9(3), 438-448. doi:10.2307/258284

Guthrie, J. P., \& Datta, D.K. (2008). Dumb and dumber: The impact of downsizing on firm performance as moderated by industry conditions. Organization Science, 19(1), 108-123.

Hayes, A. F., \& Matthes, J. (2009). Computational procedures for probing interactions in OLS and logistic regression: SPSS and SAS implementations. Behavior Research Methods, 41(3), 924-936. doi:10.3758/ BRM.41.3.924

Kurtessis, J. N., Eisenberger, R., Ford, M. T., Buffardi, L. C., Stewart, K. A., \& Adis, C. S. (2017). Perceived organizational support: A meta-analytic evaluation of organizational support theory. Journal of Management, 43(6), 1854-1884. doi:10.1177/0149206315575554

Lee, S. H., \& Jeong, D. Y. (2017). Job insecurity and turnover intention: Organizational commitment as mediator. Social Behavior and Personality: An International Journal, 45(4), 529-536. doi:10.2224/sbp.5865

Lim, V. K. (1996). Job insecurity and its outcomes: Moderating effects of work-based and nonwork-based social support. Human Relations, 49(2), 171-194. doi:10.1177/001872679604900203
López, S., Bal, P. M., Jansen, P. G., Leiva, P. I., \& Alonso, A. M. (2017). How mass layoffs are related to lower job performance and OCB among surviving employees in Chile: An investigation of the essential role of psychological contract. The International Journal of Human Resource Management, 28(20), 2837-2860.

Luchak, A. A., \& Gellatly, I. R. (2007). A comparison of linear and nonlinear relations between organizational commitment and work outcomes. Journal of Applied Psychology, 92(3), 786-793. doi:10.1037/0021-9010.92.3.786

Lynch, P., Eisenberg, R., \& Armeli, S. (1999). Perceived organizational support: Inferior versus superior performance by wary employees. Journal of Applied Psychology, 84(4), 467-483. doi:10.1037/00219010.84.4.467

Marques, T., Galende, J., Cruz, P., \& Portugal Ferreira, M. (2014). Surviving downsizing and innovative behaviors: A matter of organizational commitment. International Journal of Manpower, 35(7), 930-955. doi:10.1108/IJM-03-2012-0049

Meyer, J. P., \& Allen, N. J. (1991). A three-component conceptualization of organizational commitment. Human Resource Management Review, 1(1), 61-89. doi:10.1016/1053-4822(91)90011-Z

Meyer, J. P., Stanley, D. J., Herscovitch, L., \& Topolnytsky, L. (2002). Affective, continuance, and normative commitment to the organization: A meta-analysis of antecedents, correlates, and consequences. Journal of Vocational Behavior, 61(1), 20-52. doi:10.1006/jvbe.2001.1842

Morrison, E., \& Robinson, S. L. (1997). When employees feel betrayed: A model of how psychological contract violation develops. Academy of Management Review, 22(1), 226-256. doi:10.2307/259230

Moshoeu, A. N., \& Geldenhuys, D. J. (2015). Job insecurity, organisational commitment and work engagement among staff in an open distance learning institution. Southern African Business Review, 19(1), 22-43.

Muthén, L. K., \& Muthén, B. O. (2010). Mplus User’s Guide: Statistical Analysis with Latent Variables: User's Guide. Muthén \& Muthén.

Preacher, K. J., \& Hayes, A. F. (2004). SPSS and SAS procedures for estimating indirect effects in simple mediation models. Behavior Research Methods, Instruments, \& Computers, 36(4), 717-731. doi:10.3758/BF03206553

Restubog, S., \& Bordia, P. (2006). Workplace familism and psychological contract breach in the Philippines. Applied Psychology, 55 (4), 563-585. doi:10.1111/j.1464-0597.2006.00245.x

Rhoades, L., \& Eisenberger, R. (2002). Perceived organizational support: A review of the literature. Journal of Applied Psychology, 87(4), 698-714. doi:10.1037/0021-9010.87.4.698

Robinson, S. L., \& Morrison, E. (1995). Psychological contracts and OCB: The effect of unfulfilled obligations on civic virtue behavior. Journal of Organizational Behavior, 16(3), 289-298. doi:10.1002/ job.4030160309

Rodrigues, A. C. de A. (2011). Trabalhador entrincheirado ou comprometido? Delimitação dos vínculos do indivíduo com a organização (Tese de Doutorado). Universidade Federal da Bahia, Salvador, Bahia. Retrieved from https://repositorio.ufba.br/ri/bitstream/ri/18772/1/ Ana\%20Carolina\%20de\%20Aguiar\%20Rodrigues\%20(tese).pdf 
Roskies, E., \& Louis-Guerin, C. (1990). Job insecurity in managers: Antecedents and consequences. Journal of Organizational Behavior, 11(5), 345-359. doi:10.1002/job.4030110503

Ruvio, A., \& Rosenblatt, Z. (1998). Sectoral differences in the experience of job insecurity: The Case of Israeli schoolteachers. Retrieved from https://eric.ed.gov/?id=ED424698

Sahdev, K. (2003). Survivors' reactions to downsizing: The importance of contextual factors. Human Resource Management Journal, 13(4), 56-74. doi:10.1111/j.1748-8583.2003.tboo105.x

Schumacher, D., Schreurs, B., Van Emmerik, H., \& De Witte, H. (2015). Explaining the relation between job insecurity and employee outcomes during organizational change: A multiple group comparison. Human Resource Management, 55(5), 809-827. doi:10.1002/hrm.21687

Shoss, M. K. (2017). Job insecurity: An integrative review and agenda for future research. Journal of Management, 43(6), 1911-1939. doi:10.1177/0149206317691574

Siders, M. A., George, G., \& Dharwadkar, R. (2001). The relationship of internal and external commitment foci to objective job performance measures. Academy of Management Journal, 44(3), 570-579. doi:10.2307/3069371

Sora, B., Caballer, A., \& Peiró, J. M. (2010). The consequences of job insecurity for employees: The moderator role of job dependence. International Labour Review, 149(1), 59-72. doi:10.1111/j. 1564-913X.2010.00075.X

Stecher, A. (2012). Perfiles identitarios de trabajadores de grandes empresas del retail en Santiago de Chile: Aportes psicosociales a la comprensión de las identidades laborales. Psykhe (Santiago), 21(2), 9-20.
Suazo, M., \& Stone-Romero, E. (2011). Implications of psychological contract breach: A perceived organizational support perspective. Journal of Managerial Psychology, 26(5), 366-382. doi:10.1108/02683941111138994

Sverke, M., \& Hellgren, J. (2002). The nature of job insecurity: Understanding employment uncertainty on the brink of a new millennium. Applied Psychology, 51(1), 23-42. doi:10.1111/1464-0597.0077z

Tian, Q., Zhang, L., \& Zou, W. (2014). Job insecurity and counterproductive behavior of casino dealers-the mediating role of affective commitment and moderating role of supervisor support. Interna tional Journal of Hospitality Management, 40, 29-36. doi:10.1016/j. ijhm.2014.03.005

Turnley, W. H., Bolino, M. C., Lester, S. W., \& Bloodgood, J. M. (2003). The impact of psychological contract fulfillment on the performance of in-role and organizational citizenship behaviors. Journal of management, 29(2), 187-206. doi:10.1016/S0149-2063(02)00214-3

Ugboro, I. O. (2003). Influence of managerial trust on survivors' perceptions of job insecurity and organizational commitment in a post restructuring and downsizing environment. The Journal of Behavioural and Applied Management, 4(3), 230-253.

Vandenberghe, C., Bentein, K., \& Stinglhamber, F. (2004). Affective commitment to the organization, supervisor, and work group: Antecedents and outcomes. Journal of Vocational Behavior, 64(1), 47-71. doi:10.1016/So001-8791(03)00029-0

Wang, H. J., Lu, C. Q., \& Siu, O. L. (2015). Job insecurity and job performance: The moderating role of organizational justice and the mediating role of work engagement. Journal of Applied Psychology, 100(4), 1249-1258. doi:10.1037/ao038330 